\title{
Discussion: Crossing the Severn estuary, UK: challenges past and present
}

1 Edmund T. Bradley OBE, BSC, CEng, MICE, MIHT Former Team Leader, Highways Agency and Project Manager for the Second Severn Crossing (1987-1991), Bristol, UK
2 Gwilym Roberts $C B E$, FREng, FICE

Formerly Chairman, Technical Adjudication Panel, Second Severn Crossing

\section{Contribution by G. Roberts}

Having read the paper by Bradley (2010) with much interest, I should like to make the following comment.

Two remarkable facts about the Second Severn Crossing were that there were no fatalities during construction (statistically, four might have been expected) or major contractual disputes. These achievements were due to meticulous pre-construction planning, a design that was developed in tandem with the construction methodology, and a contract and concession agreement tailored to suit the demands of the project. These facts are a great tribute to all those involved in the preliminary operations and in the design and construction of the crossing, which was only the second major private finance initiative (PFI) project (the first being the QE2 Bridge at Dartford).

\section{Author's reply}

I am grateful for Gwilym's comments on the strong safety record and absence of any fatalities during construction of the Second Severn Crossing, and on the absence of any major contractual disputes and the key factors in this.

Whilst not stated in the paper, the DVD produced by the Severn Bridges Trust from original Laing GTM film recognises the excellent safety record, the absence of fatalities, and performance to time and budget, despite difficulties. Mizon and Kitchener (1997) comment on an incident in June 1994 when a pier unit fell $5 \mathrm{~m}$ and embedded in the deck, and recognise that it was fortuitous that the impact occurred in the mid-span region where the effects were less severe than in other areas. A major effort was made to recover time, deal with a sensitive labour dispute and correct a deficiency in the braking system on the 'crab' used for transporting the precast deck units.

In relation to developing the design, build, finance and operate (DBFO) PFI proposals, the Department of Transport recognised and drew on experience of PFI at the QE2 Bridge at Dartford. This was the starting point from which the Second
Severn Crossing proposals were developed, to the benefit of the overall scheme.

\section{REFERENCES}

Bradley ET (2010) Crossing the Severn estuary, UK: challenges past and present. Proceedings of the Institution of Civil Engineers, Engineering History and Heritage 163(4): 219229, doi: 10.1680/ehah.2010.163.4.219.

Mizon DH and Kitchener JN (1997) Second Severn crossing viaduct superstructure and piers. Proceedings of the Institution of Civil Engineers - Civil Engineering 120(6): 3548, doi: 10.1680/cien.1997.29858.

\section{WHAT DO YOU THINK?}

To discuss this paper, please email up to 500 words to the editor at journals@ice.org.uk. Your contribution will be forwarded to the author(s) for a reply and, if considered appropriate by the editorial panel, will be published as discussion in a future issue of the journal.

Proceedings journals rely entirely on contributions sent in by civil engineering professionals, academics and students. Papers should be 2000-5000 words long (briefing papers should be 1000-2000 words long), with adequate illustrations and references. You can submit your paper online via www.icevirtuallibrary.com/content/journals, where you will also find detailed author guidelines. 